\title{
Techniques for environmental monitoring of predatory fauna on branches of Bramley apple trees in Northern Ireland
}

\author{
${ }^{1 *}$ A. G. S. Cuthbertson and ${ }^{2}$ A. K. Murchie \\ ${ }^{1}$ Central Science Laboratory, Sand Hutton, York YO41 1LZ, United Kingdom \\ ${ }^{2}$ Department of Agriculture and Rural Development for Northern Ireland and the Queen's University of Belfast, Newforge Lane, \\ Belfast BT9 5PX, United Kingdom
}

\begin{abstract}
Ranges of trapping devices were investigated for their ability to sample predatory mites and insects on branches of apple trees. Straw traps caught significantly more predatory mites whereas corrugated cardboard traps proved better for larger predators such as the common earwig, Forficula auricularia. The most abundant predatory species sampled on the trees was the 'whirli-gig' mite Anystis baccarum. The efficiency of the various trapping devices and the potential of incorporating $A$. baccarum within environmentally based management strategies for invertebrate pest control within the Bramley apple orchards are discussed.
\end{abstract}

Key words: Anystis baccarum, biodiversity, Bramley's Seedling apple, Forficula auricularia, pest management, predatory fauna, trapping

*Corresponding Author, E-mail: a.cuthbertson@csl.gov.uk

\section{Introduction}

A wide range of predators have been exploited, or have the potential to be exploited, as biological control agents against pests of fruit. In the British Isles, these include members of the families Miridae (mirid bugs) (Hemiptera), Anthocoridae (flower bugs) (Hemiptera), Forficulidae (earwigs) (Dermaptera) and several mite families (Solomon, 1992). Leaf-dwelling predators such as the mites Typhlodromus pyri and Zetzellia mali can be sampled by leaf washings (Zacharda, et al., 1988). However, larger predatory species are generally more mobile and cannot be sampled in this way as they disperse when vegetation is disturbed. Various authors have used artificial shelter traps for trapping F. auricularia and other insect fauna (Chant and McLeod, 1952; Campbell, 1978; McAdam, et al., 1994 and Helsen, et al., 1998) and mites (Morgan and Anderson, 1958). Similarly, sticky traps in the form of grease bands have been used to trap mites (Staples and Allington, 1959) and mirids (Stewart and Gaylor, 1991). However, little information is available regarding the effectiveness of different trapping systems in sampling the predatory fauna on branches of apple trees. The aim of this study was to compare several different techniques for trapping and hence sampling the predatory fauna from branches of apple trees, and to determine the most abundant predatory species within Northern Irish apple orchards.

\section{Materials and Methods \\ Study orchard}

The study site was a commercially active Bramley's seedling apple orchard at Loughgall, County Armagh, Northern Ireland (N 054 24.3' W $006^{\circ} 35.8^{\prime}$ ). This orchard received normal fungicide spray treatment to control apple scab (Venturia inaequalis) but no acaricide treatments.

\section{Interception traps}

One of each trap type (Table 1) was attached to different branches of each of ten randomly chosen trees, from 17 March until 28 August 1997. The traps were changed at fortnightly intervals and placed under Tullgrën funnels for 24 hours where predatory arthropods were expelled into $30 \%$ ethanol. All specimens were identified and recorded. Numbers of predatory mites and insects captured in the traps were subjected to analysis of variance (ANOVA).

\section{Leaf washing}

Over the same time period as the trapping experiment, leaf samples were taken at fortnightly intervals from the apple trees (8 leaves per sample date) and, following the method of Zacharda et al. 
Table 1: Trapping devices used to capture predatory fauna on branches of apple trees

\begin{tabular}{|c|c|c|}
\hline Trap type & Construction & $\begin{array}{c}\text { Dimensions } \\
\text { ( } \mathrm{L}=\text { length, } \mathrm{W}=\text { width, } \mathrm{D}=\text { depth) }\end{array}$ \\
\hline Straw & $\begin{array}{c}\text { Nylon mesh bag }(5 \times 3 \mathrm{~mm} \text {. rectangular mesh) } \\
\text { containing heat-sterilised }\left(48 \mathrm{~h} \text {. at } 55^{\circ} \mathrm{C}\right) \text { chopped } \\
\text { barley straw }\end{array}$ & L- 50 mm.,W- 90 mm. \\
\hline $\begin{array}{l}\text { Corrugated } \\
\text { Cardboard }\end{array}$ & $\begin{array}{l}\text { Corrugated cardboard (L-150 mm., W-190 mm., } 3 \\
\text { mm ridged cardboard) rolled up inside open-ended } \\
\text { plastic cylinders }\end{array}$ & L- 200 mm., Dia. 50 mm. \\
\hline $\begin{array}{l}\text { Ridged } \\
\text { Corriboard } \\
\text { (Single sheet) }\end{array}$ & Single sheet of laminated corrugated Corriboard & L-140 mm., W-90 mm., D-4 mm. \\
\hline $\begin{array}{l}\text { Multi-layer } \\
\text { Corriboard trap } \\
\text { (Layered) }\end{array}$ & Three sheets of laminated corrugated Corriboard & L-14 cm. ,W-9 cm., D-13 mm. \\
\hline Sticky & $\begin{array}{c}\text { Single-sided yellow sticky continuous trap paper } \\
\text { (Agralan Ltd. Swindon, UK) wrapped around the } \\
\text { branch }\end{array}$ & $\mathrm{W}-120 \mathrm{~mm}$. \\
\hline
\end{tabular}

Table 2: Mean number ( \pm SEM) of predatory mites per leaf $(n=8)$ averaged over 12 fortnightly samples from 17 March until 28 August 1997 in a non-acaricide sprayed Bramley orchard

\begin{tabular}{|lccc|}
\hline \multicolumn{1}{|c}{ Predatory mite } & Family & Mean per leaf \\
\hline Typhlodromus pyri & Scheuten & Phytoseiidae & $0.15 \pm 0.11$ \\
Phytoseius macropilis & (Banks) & Phytoseiidae & $0.11 \pm 0.08$ \\
Zetzellia mali & (Ewing) & Stigmaeidae & $0.10 \pm 0.08$ \\
\hline
\end{tabular}

(1988), leaf dwelling predators were sampled. Numbers of predatory species washed from the leaves were identified and recorded.

\section{Results}

\section{Leaf washing}

Only three species of predatory mites were washed from leaves. In order of abundance they were T. pyri, Phytoseius macropilis and Z. mali (Table 2).

\section{Interception traps}

The most numerous predatory species obtained from the traps was the generalist predatory mite, Anystis baccarum (Table 3).

Straw traps trapped more predatory mites $(\mathrm{F}=$ 11.38, d.f.=4,36, $\mathrm{P}<0.01$ ), including A. baccarum, compared to the other traps. However, corrugated cardboard traps trapped the majority of larger predators $(\mathrm{F}=2.99$, d.f. $=4,36, \mathrm{P}=0.03)$ (Table 3); in particular, F. auricularia. The sticky traps were impractical as they quickly became covered with flies which made sorting of small predatory mites extremely difficult.

\section{Discussion and Conclusion}

The presence of the phytoseiid and stigmaeid mites in leaf washings from this non-acaricide sprayed orchard was expected. Typhlodromous pyri is widespread and abundant on various trees, shrubs, and herbaceous plants (Collyer, 1964) and is common in both intensively managed and wild orchards. In the present study, the density of $T$. pyri at 0.15 mites per leaf was smaller than that in a dessert orchard in southern England where the population reached 0.25 per leaf (Cross and Berrie, 1994). Similarly, $P$. macropilis is a widespread predator of both eriophyid (rust mites) and tetranychid (red spider mites) mites on several host plants, including unsprayed apple and plum trees (Alford, 1984). Zetzellia mali is also considered a common predator of Aculus schlechtendali (rust mite) and Panonychus ulmi (red spider mite) on fruit trees (Santos, 1976; Alford, 1984). 


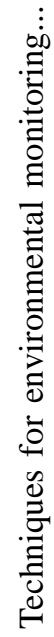

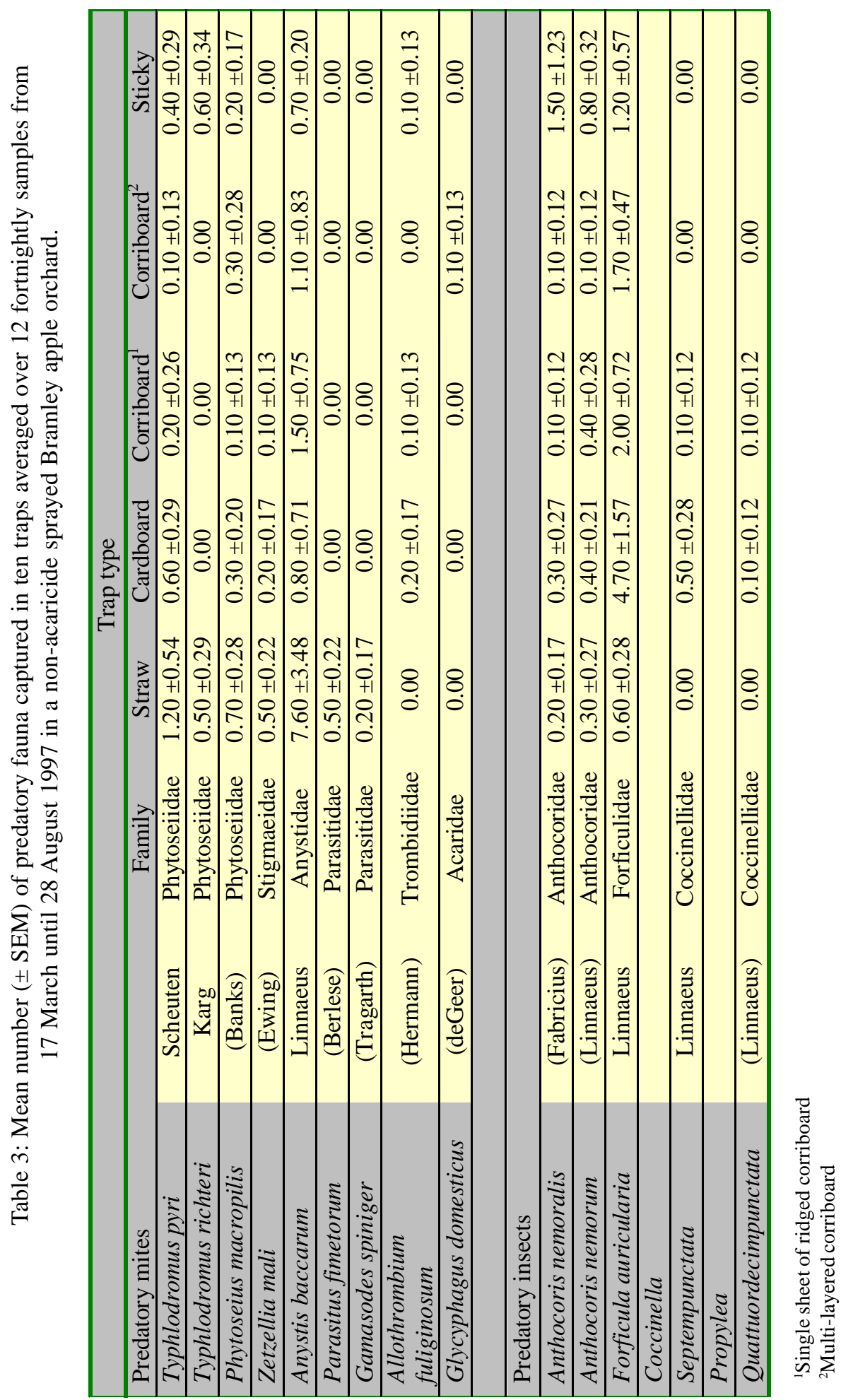


The most abundant predatory species caught in traps and visible on the trees in this orchard was the predatory mite, Anystis baccarum (Linnaeus). Anystis baccarum has been little researched in orchards in the British Isles, and their abundance remains relatively unknown (Cuthbertson and Murchie, 2004a). As all members of this family are generalist predators which feed readily on a wide range of arthropods (Baker, 1967), this species could be a valuable natural enemy of orchard pests (Cuthbertson, 2000; Cuthbertson and Murchie, 2000; Cuthbertson and Murchie, 2004b).

The most abundant predatory species caught in traps and visible on the trees in this orchard was the predatory mite, Anystis baccarum (Linnaeus). Anystis baccarum has been little researched in orchards in the British Isles, and their abundance remains relatively unknown (Cuthbertson and Murchie, 2004a). As all members of this family are generalist predators which feed readily on a wide range of arthropods (Baker, 1967), this species could be a valuable natural enemy of orchard pests (Cuthbertson, 2000; Cuthbertson and Murchie, 2000; Cuthbertson and Murchie, 2004b). Baker (1983) noted that $A$. baccarum preyed on leafrolling caterpillars in apple orchards in New Zealand and Putman and Herne (1966) found A. baccarum numbers to increase in orchards during outbreaks of P. ulmi in Ontario. Cuthbertson et al. (2003a,b) and Cuthbertson and Murchie (2003a; 2004a) went on to show that $A$. baccarum readily preyed upon $A$. schlechtendali, P. ulmi, Rhopalosiphum insertum (apple-grass aphid) and Bryobia rubrioculus (apple brown mite) within the Bramley apple orchards. The former three of these species are economically important pests in Northern Irish apple orchards (Mowat and Clawson, 1996).

A range of other common predatory arthropods were found in the traps. These are mainly generalist predators but will also be instrumental in reducing pest numbers to some extent. The most common large predator was F. auricularia which probably makes an important contribution to predation of pest species but they are of dubious value in orchards because they can also cause damage to the apples (Croxall et al., 1951; Sial, 1957). Another predator caught, the ladybird, Coccinella septempunctata, is attracted into orchards by outbreaks of aphids (Collyer, 1953). However, if as a result of spraying or predatory activity the aphids become scarce, the larvae of this species will also feed upon P. ulmi. In this way a slight infestation of aphids in May and June may contribute to $P$. ulmi control by attracting adult $C$. septempunctata into the orchards (Collyer, 1953).

Predacious mites and insects are usually sampled by the same method as the prey they feed on (Huffaker et al., 1970). However, this method may not always present a complete picture of the populations of certain species. Putman and Herne (1964) found that a large proportion of the population of Typhlodromus caudiglans Schuster, was found on twigs. The difficulty arises because some species move back to sheltering crevices or rough surfaces when fully fed or during daytime. In addition, many insect predators of mites may drop from the leaves or fly away when leaves or twigs are being removed from the plants (Huffaker et al., 1970). The use of traps offers shelter from the climate by mimicking natural crevices and prevents foliage or twigs from being disturbed when sampling.

Each type of trap caught both predatory mites and insects. The straw traps proved the best for trapping mites, especially A. baccarum. This may simply be related to the size of the mesh. Larger predators such as $F$. auricularia may have had difficulty trying to squeeze through the mesh openings. When inside the trap, the straw would offer good protection from changing climatic conditions and also a possible shelter for prey. Collembola were commonly found in the straw traps where $A$. baccarum were observed to readily prey upon them (Cuthbertson, AGS, personal observation).

The corrugated cardboard traps were useful for trapping fauna in hedgerow restoration studies (McAdam et al., 1994). In this study, F. auricularia were taken more frequently in this trap compared to the others. Campbell (1978) and Helsen et al. (1998) found corrugated cardboard traps to work well for trapping F. auricularia which aligned themselves in the corrugations during the day and returned to the same roost each night. The corriboard traps trapped larger predators in much the same way as the corrugated cardboard traps.

This study has highlighted the need for a range of assessment techniques for sampling predatory fauna on apple trees. Lord (1965) commented that there is no ideal method for monitoring predators on apple trees because of their non-random distribution, variation in foliage growth, and the active nature of many predators. The tendency to sample for beneficial mite predators such as T. pyri and Z. mali by washing leaves may lead to an underestimation of the role of more mobile mite predators such as $A$. baccarum. Cuthbertson and Murchie (2004a) 
investigated the seasonal abundance of $A$. baccarum within Northern Irish orchards and demonstrated how its population peaked when pest species, such as, $P$. ulmi, are beginning to increase in number. Anystis baccarum, the most abundant predator within the orchard, has the potential to control various invertebrate pest species (Cuthbertson et al., 2003a,b; Cuthbertson and Murchie, 2004a) and also is compatible with various chemical fungicides (Cuthbertson and Murchie, 2003a). Therefore, encouraging the presence and population build up of $A$. baccarum and other predatory fauna within the orchards will help reduce pest populations. Also, enabling fruit growers to recognise $A$. baccarum as a beneficial species will help ensure its survival within the orchard ecosystem (Cuthbertson and Murchie, 2003b; Cuthbertson, 2004, 2005). The greater the biodiversity of predatory fauna within a relatively stable ecosystem like an orchard, then the more natural control and less reliance on chemical insecticides. This also alleviates consumer concerns, justified or not, regarding the build-up of chemical residues on fruit produce and helps move the apple industry into a more environmentally sustainable production system.

This study has shown that a range of trapping devices are necessary for sampling predatory fauna on branches of apple trees. Anystis baccarum was the most abundant predatory species sampled in the orchard. This mite has potential to be incorporated into environmentally based management strategies for the control of invertebrate pests. Fruit growers should be encouraged to conserve, not only $A$. baccarum, but all predatory fauna populations within their orchards.

\section{Acknowledgement}

Dr Andrew G. S. Cuthbertson was funded by a Department of Agriculture and Rural Development (Northern Ireland) Studentship.

\section{References}

Alford, D. V., A colour atlas of fruit pests, their recognition, biology and control. Wolfe Publishing Ltd. London: 320, 1984

Baker, R. T., Predation of leafroller larvae by spiders and mites. Weta, 6: 22-23, 1983

Baker, W. V., Some observations on predation in an anystid mite. Entomol. Mon. Mag., 103: 58-59, 1967
Campbell, C. A. M., Regulation of the damson-hop aphid (Phorodon humuli (Schrank)) on hops (Humulus lupulus L.) by predators. J. of Hort. Sci., 53: 235242, 1978

Chant, D. A. and J. H. McLeod, Effects of certain climatic factors on the daily abundance of the European earwig, Forficula auricularia $L$. (Dermaptera: Forficulidae), in Vancouver, British Columbia. Can. Entomol., 84: 174-180, 1952

Collyer, E., Biology of some predatory insects and mites associated with the fruit tree red spider mite (Metatetranychus ulmi (Koch)) in south-eastern England. IV The predator-mite relationship. J. of Hort. Sci., 28: 246-259, 1953

Collyer, E., Phytophagous mites and their predators in New Zealand orchards. New Zeal. J. of AGR. RES., 7: 551-568, 1964

Cross, J. V. and A. M. Berrie, Effects of repeated foliar sprays of insecticides or fungicides on organophosphate-resistant strains of the orchard predatory mite Typhlodromus pyri on apple. Crop Protection, 13: 39-44, 1994

Croxall, H. E., Collingwood, C. A. and J. E. E. Jenkins, Observations on brown rot (Sclerotinia fructigena) of apples in relation to injury caused by earwigs (Forficula auricularia). Ann. of Appl. Biol., 38: 833843, 1951

Cuthbertson, A. G. S., The role of the predatory mite, Anystis baccarum, in Bramley apple orchards. Ph.D Thesis, The Queen's University of Belfast, UK, 170, 2000

Cuthbertson, A. G. S., Unnecessary pesticide applications in Northern Ireland apple orchards due to mis-identification of a beneficial mite species. Research Journal of Chemistry and Environment, 8 (3): 77-78, 2004

Cuthbertson, A. G. S., Re-discovery of a predatory mite in Northern Irish apple orchards. Biodiversity News, 30 (1): 29, 2005

Cuthbertson, A.G.S. and A.K. Murchie, The prospect of biological control within Northern Ireland Bramley orchards. Biology and Environment: Proceedings of the Royal Irish Academy, 100: 50, 2000.

Cuthbertson, A. G. S. and A. K. Murchie, The impact of fungicides to control apple scab (Venturia inaequalis) on the predatory mite Anystis baccarum and its prey Aculus schlechtendali (apple rust mite) in Northern Ireland Bramley orchards. Crop Protection, 22: 11251130, $2003 a$ 
Cuthbertson, A.G.S. and A.K. Murchie, The need for proper identification of beneficial and pest species in the Bramley apple orchards. Online:

www.ruralni.gov.uk/crops/fruit/top_fruit/ technical_information/proper_identification.htm. Accessed January 2005: 3, 2003 b

Cuthbertson, A. G. S. and A. K. Murchie, The phenology, oviposition and feeding rate of Anystis baccarum, a predatory mite in Bramley apple orchards in Northern Ireland. Exp. Appl. Acarol., 34: 367-373, 2004a

Cuthbertson, A. G. S. and A. K. Murchie, The presence of Anystis baccarum (L.) in Northern Ireland Bramley apple orchards. Ir. Nat. J., 27: 465-467, 2004b

Cuthbertson, A. G. S., Bell, A. C. and A. K. Murchie, The impact of the predatory mite Anystis baccarum on apple rust mite (Aculus schlechtendali) populations in Northern Ireland Bramley orchards. Ann. Appl. Biol., 142: 107-114, 2003a

Cuthbertson, A. G. S., C. C. Fleming, and A. K. Murchie, Detection of Rhopalosiphum insertum (apple-grass aphid) predation by the predatory mite Anystis baccarum using molecular gut analysis. Agric. Forest Entomol., 5: 219-225, 2003b

Helsen, H., Vaal, F. and L. Blommers, Phenology of the common earwig Forficula auricularia $L$. (Dermaptera:Forficulidae) in an apple orchard. Int. J. of Pest Manage., 44: 75-79, 1998

Huffaker, C. B., M. Van de Vrie, and J. A. McMurtry, Ecology of tetranychid mites and their natural enemies: a review II. Tetranychid populations and their possible control by predators: An evaluation. Hilgardia, 40: 391-458, 1970

Lord, F. T., Sampling predator populations on apple trees in Nova Scotia. Can. Entomol., 97: 287-298, 1965

McAdam, J. H., Bell, A. C. and T. Henry, The effect of restoration techniques on flora and microflora of hawthorn-dominated hedges. In: Watt, T. A. and G. P. Buckley (eds): Hedgerow Management and Nature Conservation. Wye College Press. Wye: 25-32, 1994
Morgan, C. V. G. and N. H. Anderson, Techniques for biological studies of tetranychid mites, especially Bryobia arborea M. \& A. and B. praetiosa Koch. (Acarina:Tetranychidae). Can. Entomol., 90: 212-215, 1958

Mowat, D. J. and S. Clawson, The need for pest control in Northern Ireland Bramley apple orchards. Crop Protection in Northern Britain, 2: 225-230, 1996

Putman, W. L. and D. H. C. Herne, Relations between Typhlodromus caudiglans Schuster (Acarina:Phytoseiidae) and phytophagous mites in Ontario peach orchards. Can. Entomol., 96: 925-943, 1964

Putman, W. L. and D. H. C. Herne, The role of predators and other biotic agents in regulating the population density of phytophagous mites in Ontario peach orchards. Can. Entomol., 98: 808-820, 1966

Santos, M.A., Evaluation of Zetzellia mali as predator on Panonychus ulmi and Aculus schlechtendali. Environ.Entomol., 5: 187-191, 1976

Sial, N. M., The earwig as an orchard pest, Fruit Yearbook. Royal Horticultural Society, London, UK: 140-145, 1957

Solomon, M. G., Exploitation of predators in UK fruit and hop culture. Phytoparasitica, 20: 51-56, 1992

Staples, R. and W. B. Allington, The efficiency of sticky traps in sampling epidemic populations of the Eriophyid mite Aceria tulipae (K.), vector of wheat streak mosaic virus. Ann. Entomol. Soc. Am., 52: 159164, 1959

Stewart, S. D. and M. J. Gaylor, Age, sex, and reproductive status of the tarnished plant bug (Heteroptera:Miridae) colonizing mustard. Environ. Entomol., 20: 1387-1392, 1991

Zacharda, M., O. Pultar, and J. Muska, Washing technique for monitoring mites in apple orchards. Expe. Appl. Acarol., 5: 181-183, 1988 